\title{
APLIKASI E-COMMERCE SISTEM INFORMASI PENJUALAN ROLLING DOOR BERBASIS RAPID APPLICATION DEVELOPMENT
}

\author{
Muhaimin Hasanudin ${ }^{1}$, Haris Muhammad Khoirudin ${ }^{2}$, Wahyu Aldi Amroni ${ }^{3}$, \\ Shatya Silen ${ }^{4}$ \\ ${ }^{1}$ Dosen Sistem Informasi STMIK Raharja \\ ${ }^{2,3,4}$ Mahasiswa jurusan Sistem Informasi STMIK Raharja \\ muhaimin@ raharja.info
}

\begin{abstract}
The Sales system at PT. Mandiri Work is done by the buyer coming directly to the seller to make a sales transaction, the transaction is processed using the MS Excell application program, resulting in no data history or log data and data difficult to use together and when data reconciliation takes a long time. From the above problems, the authors make improvements to the system in the form of e-Commerce-based Rolling Door sales information system that aims to process sales data for Rolling Door. In this study using the Rapid Application Development (RAD) model, which begins with data collection, analysis and system design that involves users to reach the desired system and ends with the implementation of the system.
\end{abstract}

Keywords: Sales system, E-Commerce, Rapid Application Development

\begin{abstract}
ABSTRAK
Sistem penjualan pada PT. Karya Mandiri dilakukan dengan cara pembeli datang langsung ke penjual untuk melakukan transaksi penjualan, transaksi tersebut diolah menggunakan program aplikasi MS Excell, sehingga mengakibatkan tidak ada histori data atau data log dan data sulit digunakan secara bersama sama serta saat rekonsiliasi data membutuhkan waktu yang lama. Dari permasalahan diatas, penulis melakukan perbaikan sistem berupa sistem informasi penjualan Rolling Door yang berbasis e-Commerce yang bertujuan untuk pengolahan data penjualan Rolling Door. Dalam penelitian ini menggunakan model Rapid Application Development (RAD) yang diawali dengan pengumpulan data, analisa dan perancangan sistem yang melibatkan pengguna hingga mencapai sistem yang diingikan dan diakhiri dengan implementasi sistem.
\end{abstract}

Kata Kunci-Rapid Application Development, penjualan, Rolling Door. 


\section{JURNAL PETIR}

Vol. 12, No. 1, Maret 2019, P-ISSN 1978-9262, E-ISSN 2655-5018

\section{Pendahuluan}

Perkembangan teknologi komunikasi dan telekomunikasi yang disertai dengan berbagai perubahan dalam mengelola bisnis telah menempatkan internet sebagai media interaksi yang sangat menjanjikan. Internet memberikan informasi dan memudahkan dalam menjalankan aktivitas sehari hari yang dibutuhkan dalam menjalankan bisnis. Salah satu produk yang dihasilkan internet adalah sebuah e-Commerce.

PT. Karya Mandiri Sepakat Tangerang merupakan perusahaan yang bergerak dibidang Metal Works-Sliding \& Folding Door Tracks-General Trade Etc, khususnya dibidang pintu dan garasi yang terbuat dari besi (Rolling Door). Dari sebuah flat besi sampai terjadinya pintu dan garasi besi yang dapat digunakan untuk rumah, perumahan, toko ataupun perusahaan. Saat ini, Sistem transaksi penjualan yang berjalan di PT. Karya Mandiri Sepakat dilakukan dengan cara pembeli datang langsung ke penjual, transaksi penjualan diolah dengan aplikasi MS Excell, sehingga mengakibatkan tidak ada histori data atau data log dan data sulit digunakan secara bersama sama serta saat rekonsiliasi data membutuhkan waktu yang lama. Berdasarkan hal itulah, perusahaan membutuhkan sebuah sistem informasi penjualan Rolling Door yang berbasis e-Commerce sehingga memudahkan transaksi penjualan, pengolahan data dan media promosi Rolling Door.

\section{Metode Penelitian}

Dalam penilitian ini, menggunakan model RAD dalam merancang sistem dapat mempercepat waktu dan biaya dalam pengerjaannya. penelitian sebelumnya yakni Sistem Informasi Pemasaran Rumah telah menerapkan model RAD dalam perancangannya. Dimana menghasilkan sistem penjualan rumah memenuhi kebutuhan pengguna secara terperinci dan memberikan nilai tambah untuk pencapaian tujuan dan sasaran bagi penjualan rumah. Saat perancangan sistem informasi yang biasa membutuhkan waktu minimal 180 hari, sedangkan dengan metode RAD membutuhkan waktu 30-90 hari dalam pembuatan sistem tersebut[1].

\subsection{Rapid Aplication Development}

RAD adalah metode pengembangan perangkat lunak menggunakan metode waterfall yang memfokuskan pada siklus pengembangan secara singkat[2]. Proses Analisa, perancangan dan pengembangan aplikasi dilakukan secara terus menerus sampai diketemukan kesepakatan dengan pengguna sesuai dengan perjanjian yang ada dengan dibatasi waktu selama 30-90 hari $[3,4]$.

Ada tiga tahapan pada Model RAD yakni[6].

1. Rencana Kebutuhan: User dan pengembang sistem melakukan pertemuan untuk mengumpulkan dan mengidentifikasi data yang dibutuhkan untuk membangun sistem.

2. Perancangan Sistem : Setelah kebutuhan data terpenuhi, data di analisa dan dirancang sesuai dengan permintaan dari pengguna dan melakukan perbaikan apabila terdapat ketidaksesuaian perancangan sistem selama tidak keluar dari kesepakatan kerja.

3. Implementasi : Setelah disepakati perancangan sistem oleh pengguna maka tahapan selanjutnya yakni membangun sistem oleh programmer. Setelah sistem berhasil dibangun maka dilakukan tes pengujian sistem secara internal agar tidak ada kesalahan program dan tampilan sistem. Langkah selanjutnya pengujian dilakukan bersama pengguna dan memberikan persetujuan mengenai sistem tersebut.

\subsection{Pengertian e-Commerce}

e-Commerce atau perdagangan elektronik merupakan suatu aktivitas yang berkaitan dengan penjualan, pembelian, pemasaran barang dan sistem pengumpulan data secara otomatis dengan memanfaatkan teknologi telekomunikasi dan informasi [5].

\section{Hasil dan Pembahasan}

Setelah diadakan penelitian dan analisa sistem pada PT. Karya Mandiri Sepakat, maka diketahui sistem yang ada saat ini masih bersifat semi komputerisasi dimana proses dilakukan dengan menggunakan aplikasi MS Excell sehingga mengakibatkan tidak ada histori data atau data 
log dan data sulit digunakan secara bersama sama serta saat rekonsiliasi data membutuhkan waktu yang lama. Setelah kebutuhan sistem diketahui maka langkah selanjutnya adalah merancang Aplikasi e-commerce sistem penjualan Rolling Door yang bertujuan untuk memaksimalkan pemasaran produk dan meningkatkan penjualan.

Ada beberapa usulan prosedur yang bertujuan untuk memperbaiki dan menyempurnakan sistem yang ada. Dalam menganalisa dan merancang sistem yang diusulkan, pada penelitian ini mengunakan program Visual Paradigm for UML 6.4 Enterprise Edition untuk menggambarkan Use Case Diagram, Activity diagram dan Sequence Diagram.

\subsection{Activity Diagram}

Ada dua (2) Tampilan Activity Diagram yang yakni usulan Activity Diagram Pelanggan dan Activity Diagram Admin, tampak seperti gambar 1 dan 2 berikut ini:

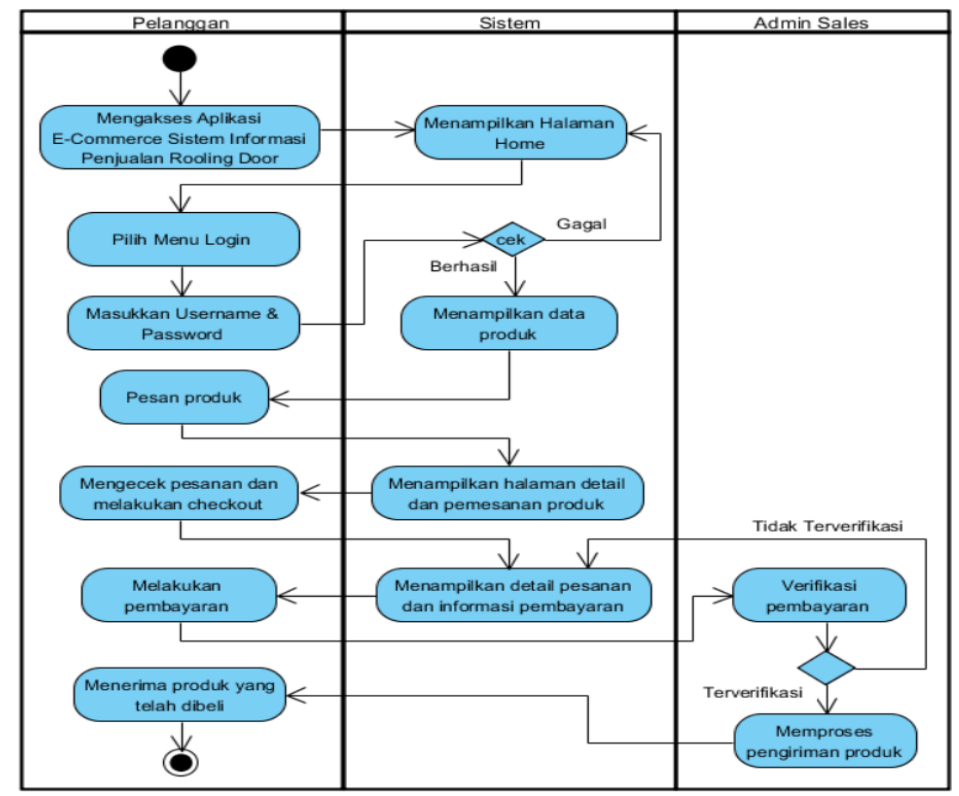

Gambar 1. Activity Diagram Pelanggan

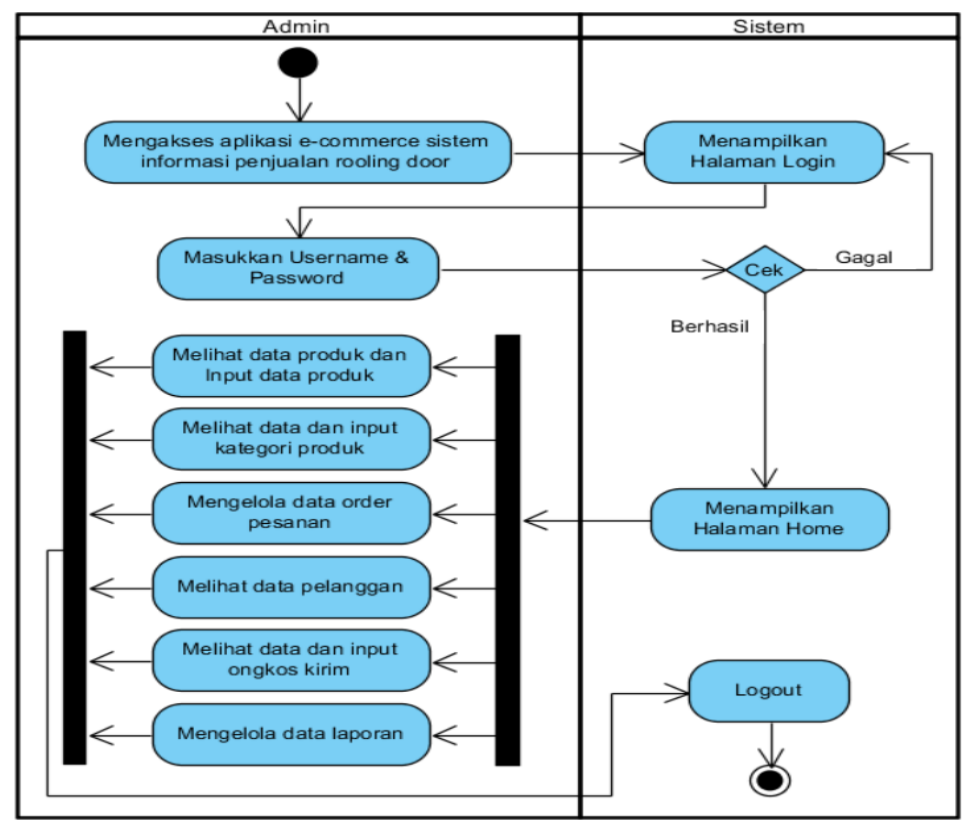

Gambar 2. Activity Diagram Admin 


\subsection{Use Case Diagram}

Pada penelitian ini digunakan program Unified Modelling Language (UML) untuk menggambarkan proses sistem yang diusulkan sesuai prosedur dengan use case diagram, yaitu sebagai berikut :

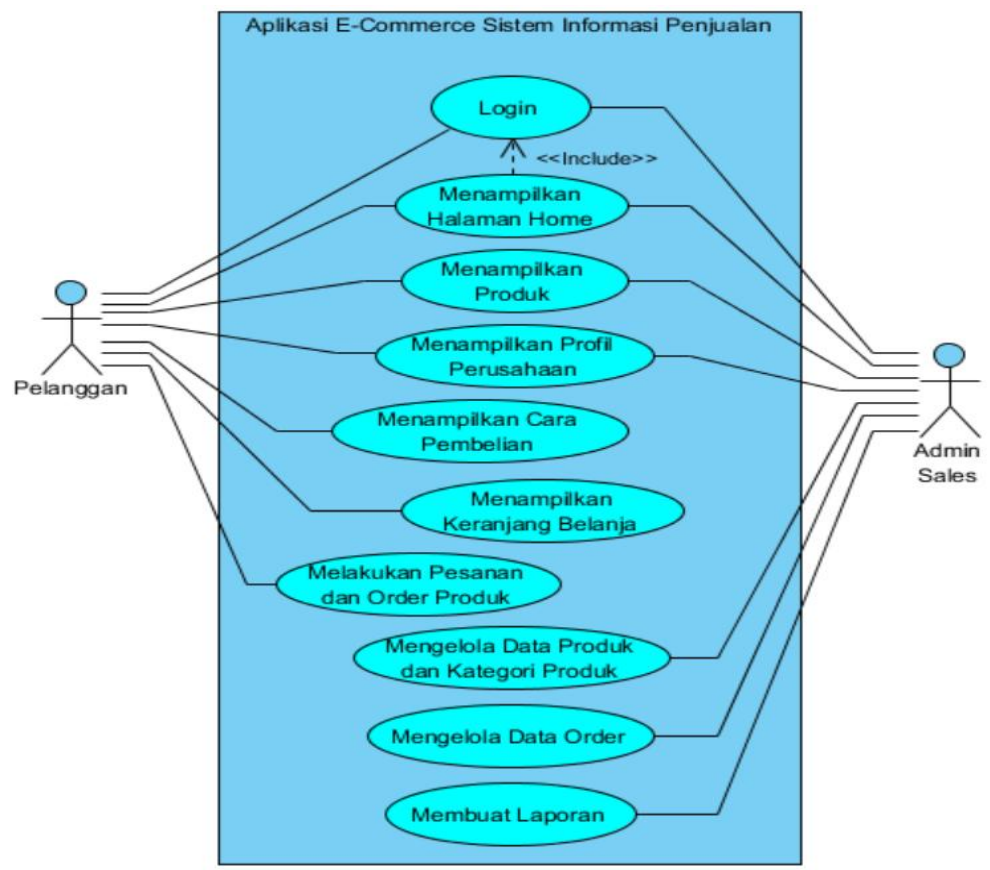

Gambar 3. Use Case Sistem Informasi Penjualan

\subsection{Sequence Diagram}

Ada dua (2) Tampilan Sequence Diagram yang yakni usulan Sequence Diagram Pelanggan dan Sequence Diagram Admin, tampak seperti berikut ini:

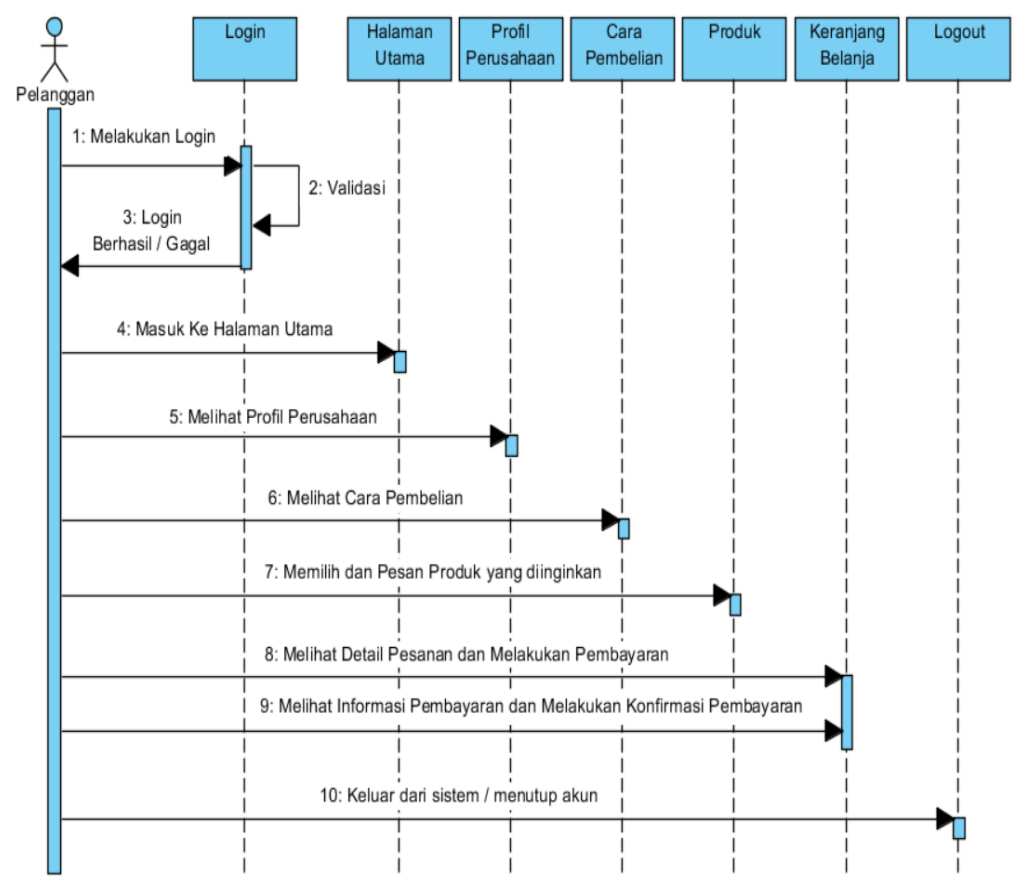

Gambar 4. Sequence Diagram Pelanggan

67| Jurnal PETIR 


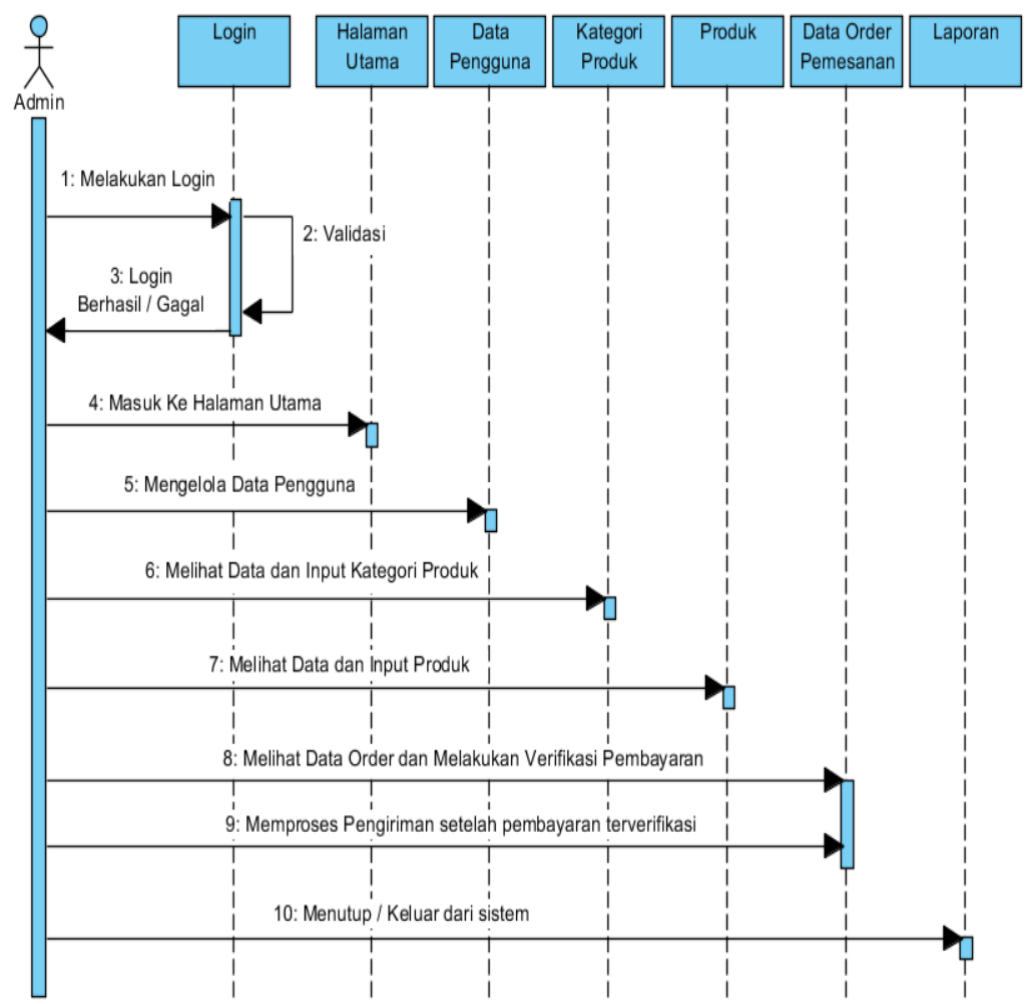

Gambar 5. Sequence Diagram Admin

\subsection{Class Diagram}

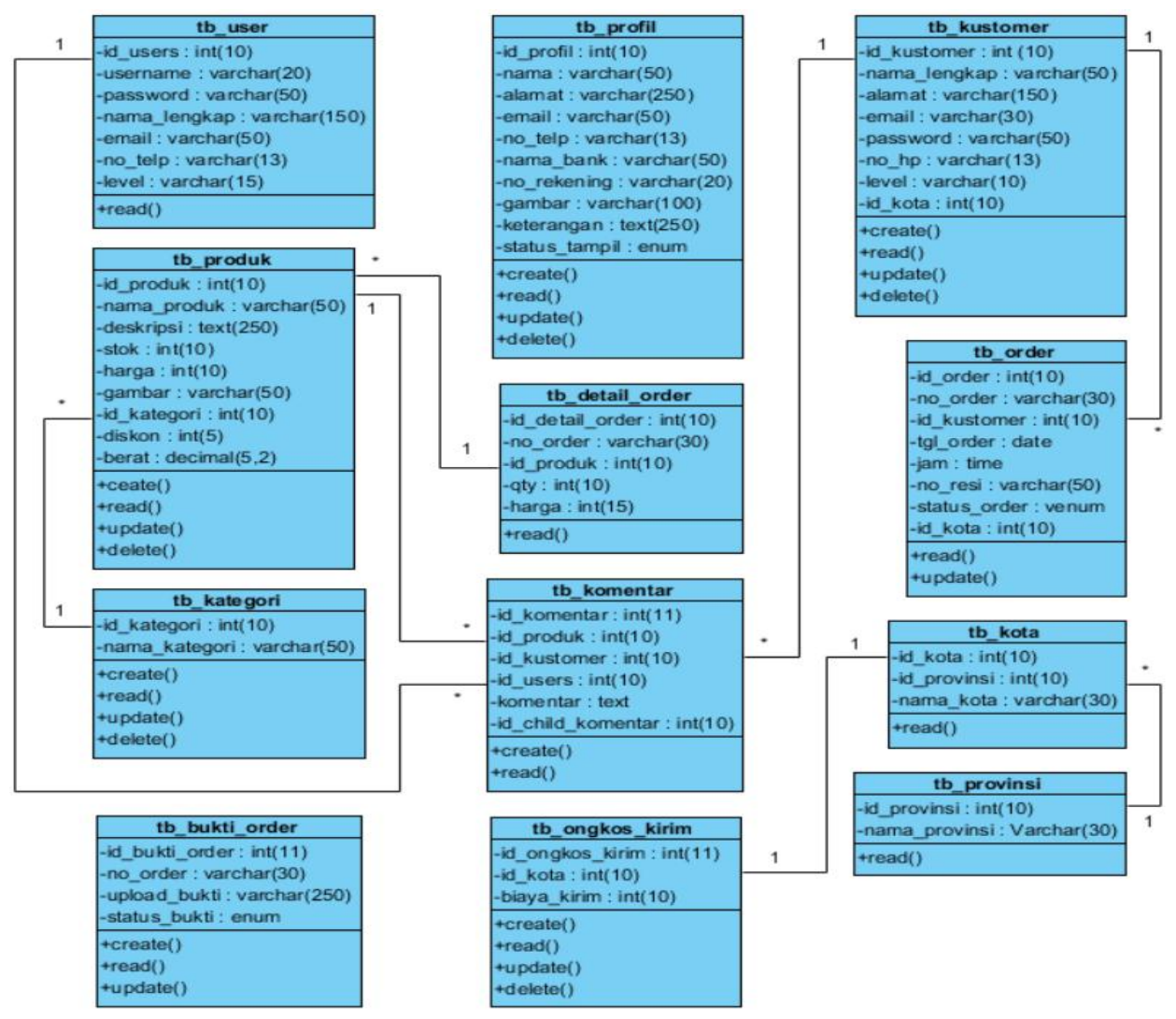

Gambar 6. Class Diagram Sistem Informasi Penjualan Rolling Door 


\subsection{Implementasi}

\section{a. Tampilan Utama}

Berikut merupakan perancangan halaman utama sistem informasi penjualan Rolling Door berbasis e-Commerce. Untuk halaman website memiliki header akan menampilkan info produk. Terdapat beberapa menu yaitu menu home yang mengarahkan pada halaman utama website, menu kategori yang mengarahkan pada kategori produk, cara pembelian, Status Pembelian, cara melakukan transaksi dan menampilkan semua produk, tampak seperti berikut ini:

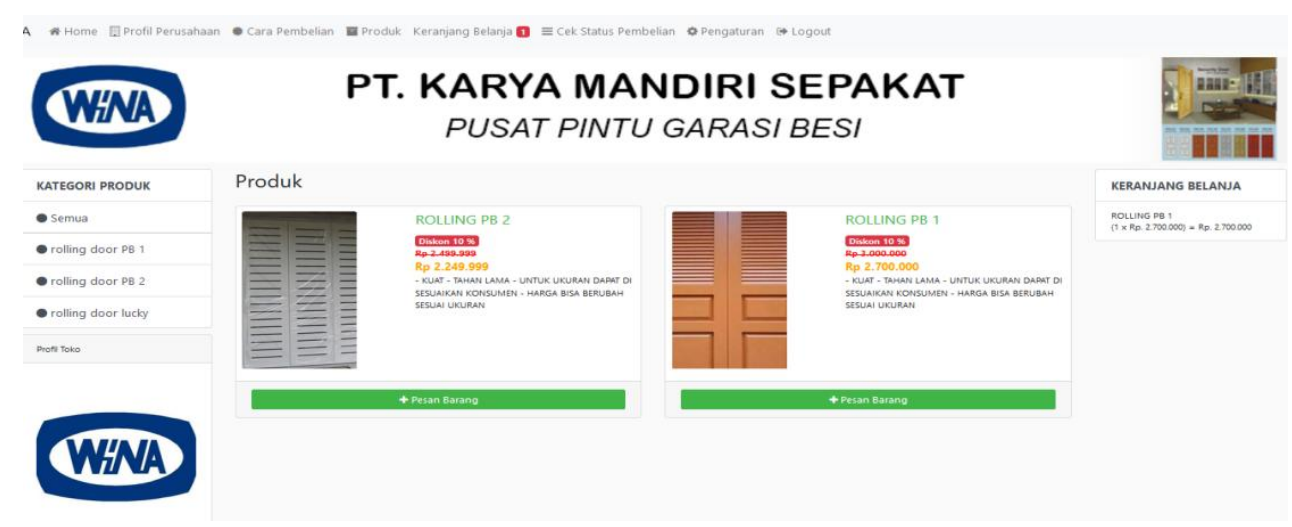

Gambar 7. Halaman Utama Sistem informasi penjualan Rolling Door

\section{b. Tampilan Order Barang}
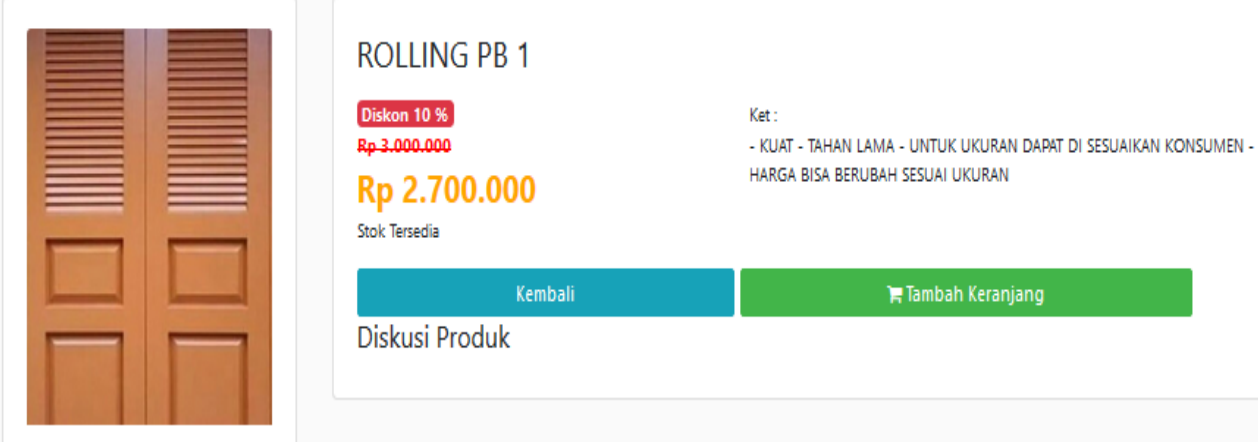

Gambar 8. Tampilan Pesan Barang

\section{c. Tampilan Transaksi}

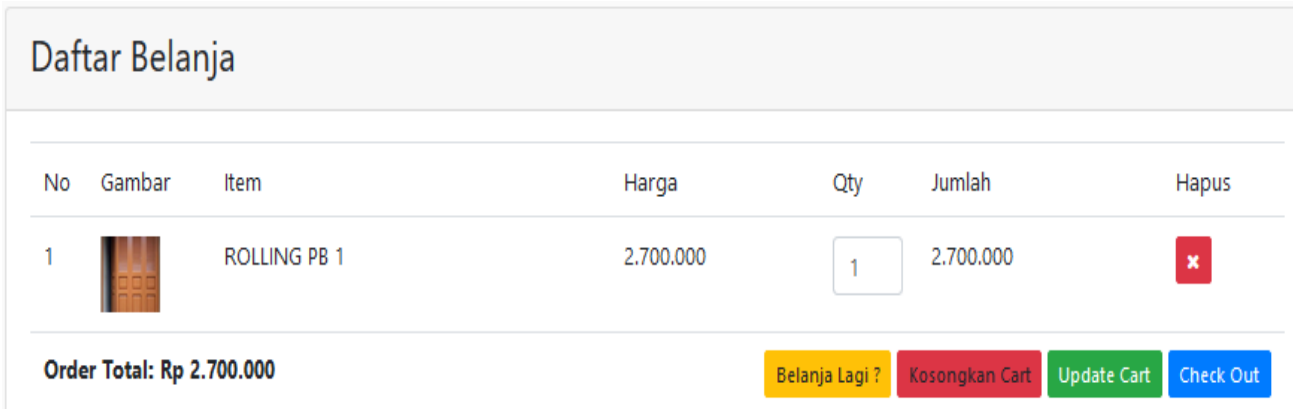

Gambar 9. Tampilan Transaksi 


\section{d. Tampilan Detail Order Barang}

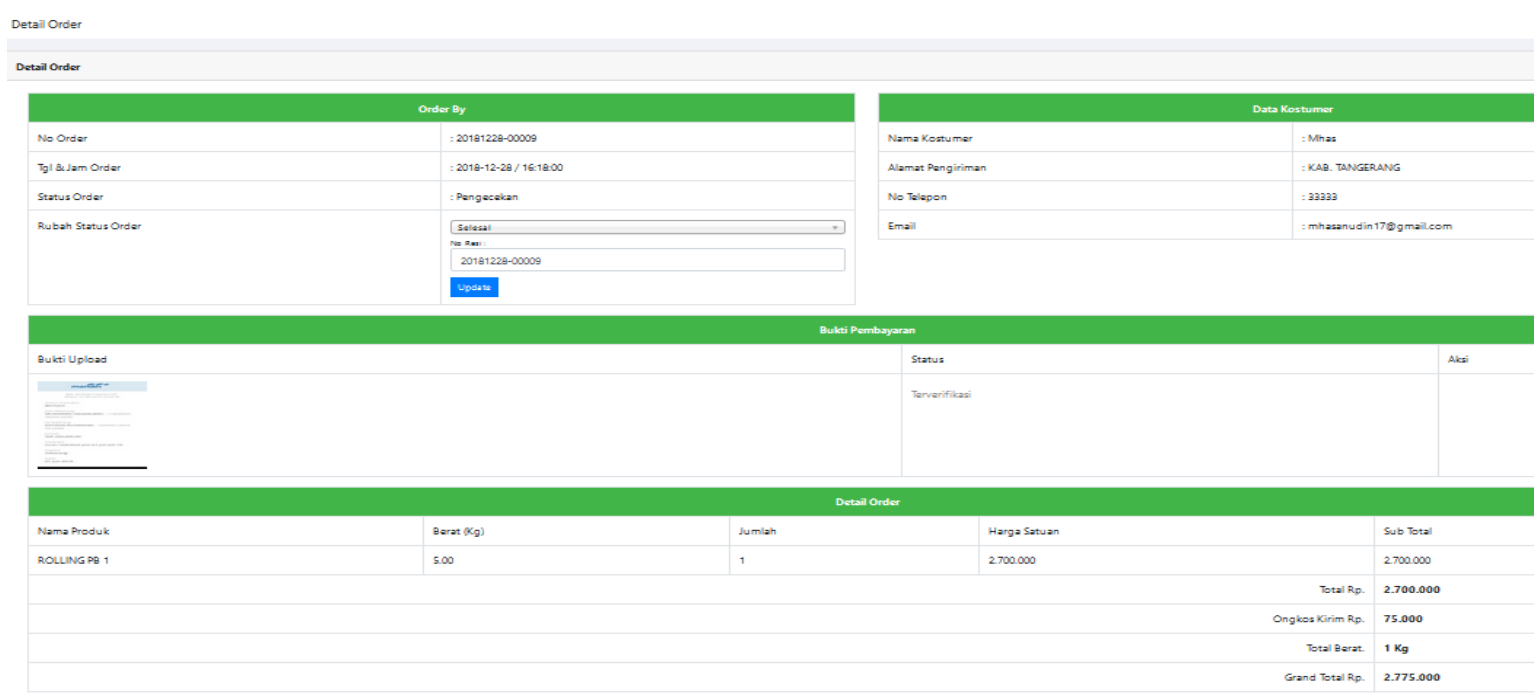

Gambar 10. Order Barang

\section{e. Tampilan Produk / Barang}

\begin{tabular}{|c|c|c|c|c|c|c|c|c|}
\hline \multicolumn{9}{|c|}{ Data Produk } \\
\hline Show 10 & $\checkmark$ entries & & & & \multicolumn{4}{|c|}{ Search: } \\
\hline No & $\begin{array}{l}\text { Nama } \\
\text { Produk }\end{array}$ & Deskripsi & Stok & $\begin{array}{l}\text { Harga } \\
\text { (Rp) }\end{array}$ & Kategori & Gambar 11 & Edit 11 & Hapus 11 \\
\hline 1 & ROLLING PB 1 & $\begin{array}{l}\text { - KUAT - TAHAN LAMA - UNTUK UKURAN DAPAT DI } \\
\text { SESUAIKAN KONSUMEN - HARGA BISA BERUBAH } \\
\text { SESUAI UKURAN }\end{array}$ & -111 & 3.000 .000 & $\begin{array}{l}\text { rolling door PB } \\
1\end{array}$ & & Edit & Hapus \\
\hline 2 & ROLLING PB 2 & $\begin{array}{l}\text { - KUAT - TAHAN LAMA - UNTUK UKURAN DAPAT DI } \\
\text { SESUAIKAN KONSUMEN - HARGA BISA BERUBAH } \\
\text { SESUAI UKURAN }\end{array}$ & 78 & 2.499 .999 & $\begin{array}{l}\text { rolling door PB } \\
2\end{array}$ & & Edit & Hapus \\
\hline Showing 1 & to 2 of 2 entries & & & & & & Previous & 1 \\
\hline
\end{tabular}

Gambar 11. Tampilan Produk / Barang

\section{f. Tampilan Laporan Data Order Barang}




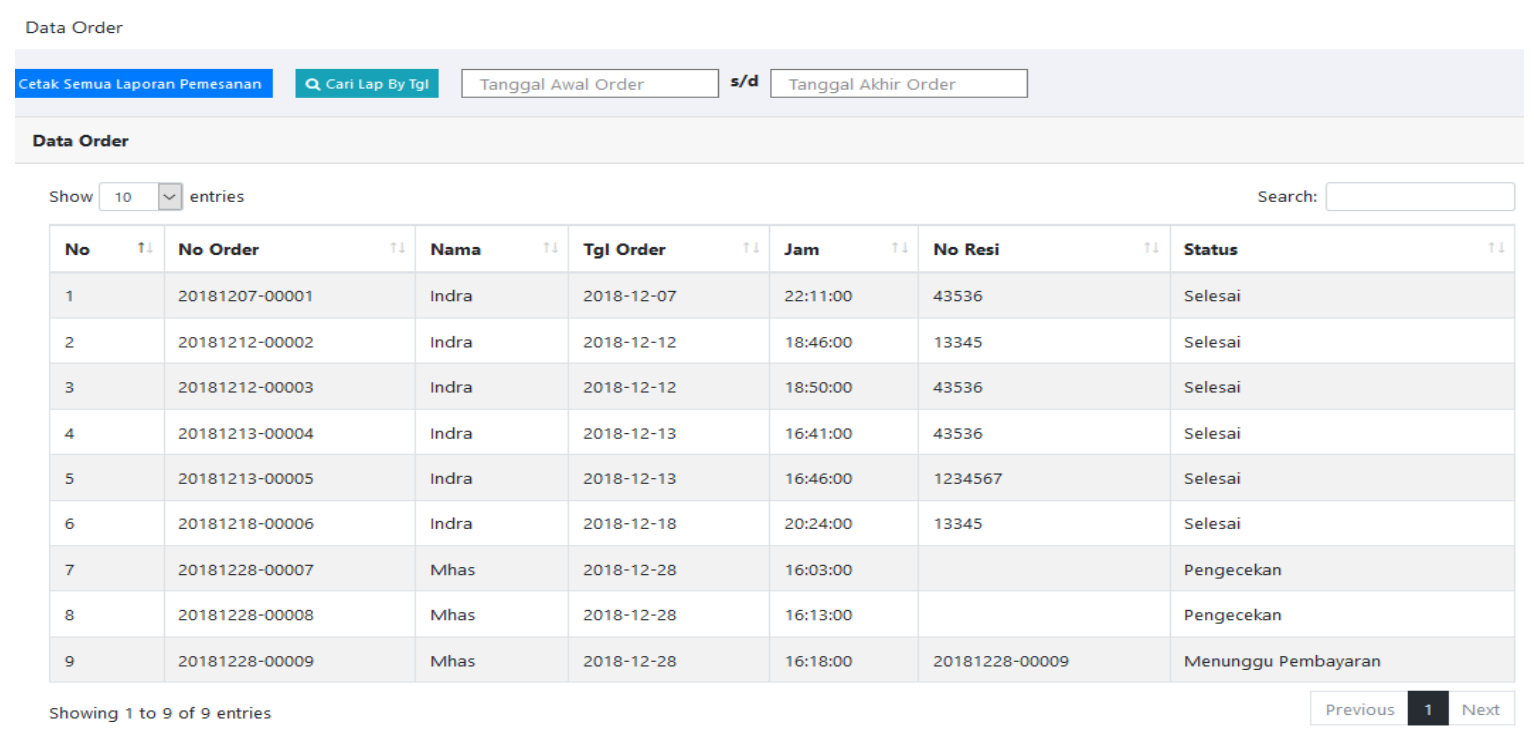

Gambar 12. Tampilan Laporan Data Order Barang

\section{Kesimpulan}

Pengembangan menggunakan metode RAD memberikan aplikasi penjualan Rolling Door memenuhi kebutuhan pengguna karena dapat menghemat waktu dalam merancang dan membangun aplikasi tersebut. Hasil pengujian menampilkan sistem memiliki fitur navigasi dalam memberikan kemudahan bagi konsumen saat mengunjungi eCommerce tersebut. konsumen dapat melakukan proses pemesanan barang secara online tanpa dibatasi ruang dan waktu.

Untuk menanggulangi permasalahan dan mencapai hasil yang lebih baik kedepannya, maka saran dan pendapat yang penulis dapat kemukakan adalah Untuk proses sistem pembayaran pada aplikasi e-commerce sistem penjualan masih dilakukan dengan sistem transfer secara manual melalui rekening Bank, kedepannya diharapakan sudah otomatis ter-verikasi dalam proses pembayarannya.

\section{Daftar Pustaka}

[1] Kosasi, Sandy, "Penerapan Rapid Application Development Dalam Sistem Perniagaan Elektronik Furniture", Citec Journal, Vol. 2 No. 4, Agustus-Oktober 2015, ISSN 2460-4259.

[2] Damayanti, Retno Wulan, Hisjam, Muh, Setiadi Haryono, 2008, "Perancangan Sistem Informasi Kepegawaian Sebagai Pendukung Keputusan Daftar Urut Kepangkatan Di Universitas Sebelas Maret Dengan Metode RAD”, Performa, Vol. 7 No. 1.

[3] Wahyuningrum, Tenia dan Januarita, Dwi, 2014, "Perancangan WEB e-Commerce dengan Metode Rapid Application Development (RAD) untuk Produk Unggulan Desa", Seminar Teknologi Informasi dan Komunikasi Terapan (Semantik), Semarang.

[4] Safrian Aswati, Yessica Siagian, 2016, "Model Rapid Application Development dalam Rancang Bangun Sistem Informasi Pemasaran Rumah (Studi Kasus : Perumnas Cabang Medan)", Semina.r Nasinal Sistem Informasi Indonesia

[5] Himawan, Asep Saefullah, Sugeng Santoso. 2014. Analisa dan Perancangan Sistem Informasi Penjualan Online (E-Commerce) Pada CV Selaras Batik, Simposium Nasional RAPI XIII 2014 FT UMS, Hal 67-73. STMIK Raharja

[6] Daud, N.M.N., Bakar, A.A.A., Rusli, H.M., 2010, Implementing Rapid Application Development (RAD) Methodology in Developing Practical Training Application System, International Symposium on Information Technology, Kuala Lumpur, Malaysia, 15 - 17 Juni 2010. 